Peer-reviewed scientific periodical, focusing on legal and economic issues of antitrust and regulation.

\title{
Disclosure of Evidence in Central and Eastern European Countries in Light of the Implementation of the Damages Directive
}

\author{
by
}

Inese Druviete, Jūlija Jerņeva, Aravamudhan Ulaganathan Ravindran*

\section{CONTENTS}

I. General procedural issues

II. Procedure for the submission of evidence

III. Criteria for the disclosure of evidence

IV. Restrictions on the disclosure of evidence

V. Disclosure of evidence by parties other than the defendant

VI. Consequences of a failure to comply with a request to submit evidence

VII. Conclusion

\section{Abstract}

The article looks primarily at the material comprised in the volume edited by A. Piszcz, Implementation of the EU Damages Directive in Central and Eastern European Countries published in 2017 and based on that compares aspects of the disclosure of evidence issue in Bulgaria, Croatia, Czech Republic, Estonia, Hungary, Latvia, Lithuania, Poland, Romania, Slovakia and Slovenia. The purpose of this article is to look into how the process for the disclosure of evidence has evolved in eleven countries of the European Union in light of Directive 2014/104/EU. The article looks at six key issues with regard to disclosure of evidence in light of Directive 2014/104/EU: general procedural issues; procedure for the submission of evidence;

* Inese Druviete - PhD, Docent, Bachelor Programme Director in Riga Graduate School of Law, Latvia, e-mail: inese.druviete@rgsl.edu.lv; Jūlija Jern,eva - PhD candidate, attorneyat-law, partner with VILGERTS law firm, specialising in EU and competition law, visiting lecturer in Riga Graduate School of Law, Latvia, e-mail: Jerneva@vilgerts.com; Aravamudhan Ulaganathan Ravindran - PhD candidate at the Riga Graduate School of Law, e-mail: au.ravindran@rgsl.edu.lv Article received: 17.07.2017; accepted: 18.08.2017. 
criteria for the disclosure of evidence; restrictions on the disclosure of evidence; disclosure of evidence by parties other than the defendant; and consequences of the failure to comply with a request to submit evidence. The article relies on primary data from eleven EU countries from Central and Eastern Europe.

\section{Résumé}

Larticle se focalise principalement sur le contenu du volume publié par A. Piszcz «Mise en oeuvre de la Directive Dommages dans les pays d'Europe centrale et orientale» publiée en 2017 et à la base de cela compare les aspects de la divulgation des preuves en Bulgarie, en Croatie, en République tchèque, en Estonie, en Hongrie, en Lettonie, en Lituanie, en Pologne, en Roumanie, en Slovaquie et en Slovénie. Le but de cet article est d'examiner comment le processus de divulgation des preuves a évolué dans onze pays de l'Union européenne à la lumière de la Directive 2014/104/UE. Larticle examine six questions clés concernant la divulgation de preuves à la lumière de la Directive 2014/104/UE: les questions de procédure générale; procédure de présentation des preuves; les critères de divulgation de la preuve; restrictions à la divulgation de la preuve; la divulgation de preuves par des parties autres que le défendeur; et les conséquences du non-respect d'une demande de présentation de preuves. Larticle s'appuie sur des données primaires de onze pays de l'UE d'Europe centrale et orientale.

Key words: private antitrust enforcement; implementation; Damages Directive; evidence.

JEL: K21

\section{General procedural issues}

There is no uniformity as regards the choice of law that governs the collection or disclosure of evidence, denotes the process that needs to be followed, and the authority responsible for the collection of evidence. Some countries have proposed a separate act (Romania, Hungary, the Czech Republic), while others incorporated it into their laws governing civil procedure (Bulgaria, Slovakia). Some have also transposed it in multiple places, like Lithuania which has a new law meant to implement Directive 2014/104/EU ${ }^{1}$ as well as introduced amendments of its civil procedure enabling those changes. This

1 Directive 2014/104/EU of the European Parliament and of the Council of 26.11.2014 on certain rules governing actions for damages under national law for infringements of the competition law provisions of the Member States and of the European Union, OJ L 349, 05.12.2014. 
part of the article should broadly deal with two illustrative issues: the impact of objective examination versus adversarial model on the disclosure of evidence, and the role of expert opinions as evidence.

The injured party in competition-based damages case is faced with the challenge to obtain the evidence needed or, indeed, to substantiate sufficiently to the court the necessity for provision of such evidence, as adversarial litigation model does not envisage the application of objective examination principle. Unlike administrative procedure, where administrative courts are free to intervene and independently decide on the type of evidence that needs to be provided, even where the parties are not skilful in formulating a clear request in adversarial proceedings, the law precludes a judge from requesting any evidence on his/her own motion and give her/his own evaluation of facts and circumstances which are not raised and interpreted by the parties. In such proceedings, it is always the parties who must either present the relevant evidence or, if unable to do so, apply to the court with a request for the taking of the evidence. The Directive prescribes that 'upon request of a claimant' with 'a reasoned justification' (Article 5.1.) specifying the items 'as precisely and narrowly as possible' (Article 5.2.) the courts 'are able to order' disclosure. Member States have implemented the above wording but it remains to be seen if that will prove sufficient to make sure that the courts actually 'have the power'. According to Recital 16, a category of evidence requested should be identified by reference to common features of its constitutive elements such as nature, content of documents or other criteria. It may easily be the case where, due to the very asymmetry of information which the Directive attempts to rectify, the claimant is unable to specify the category of evidence sought to such a degree which accounts for specifiable evidence, and the judge does not engage in specifying the request to assist. This is a likely scenario in those countries where the specific limitations to discovery set out in the Directive are looked upon as narrowing down the courts' general competences (especially leniency or settlement documents) or dealing with confidential information, as specified in accordance with the respective national interpretation.

Similarly, the adversarial model envisages in principle that a judge cannot accept evidence which is not available to all parties in the dispute, whereas the Directive requires that a judge assesses whether the request is proportionate, also in regard to divulging confidential information where the courts consider it relevant, ensuring that national courts have at their disposal effective measures to protect such information. Thus Member States have discretion to provide arrangements for dealing with confidential information other than disclosing it to both parties.

Accordingly, in some Member States a judge will not disclose a document, if it is considered to contain business secrets and the confidentiality obligation 
has not been waived by the party providing this information, appointing instead an expert to assess the damage (Hungary, Estonia). In others, courts are aided by issuing specific guidelines for dealing with confidential information (Czech Republic), stating that full information is disclosed to a limited number of persons associated with the claimant (Czech Republic, Latvia), or court appointed impartial experts who produce a report (for the purposes of the claimant) that does not contain confidential information. The courts may have a broad mandate to adopt other appropriate measures in order to protect the confidentiality of the disclosed information, such as erasing confidential information from the documents disclosed (Czech Republic). Nevertheless, critics argue that there is no measure that would prevent a competitor who is a party to an action for damages from using information obtained during a damages procedure to gain a competitive advantage, without necessarily infringing the duty of secrecy (Croatia).

This is not to say that an objective examination by courts is without these problems, or that courts are universal in applying the Directive with respect to the disclosure of evidence, the adversarial model exhibits the shortcomings of disclosure of evidence in a pronounced manner.

With regard to the role of expert witnesses, there is no uniformity either. In Latvia, a judge upon receipt of a reasoned request may decide to invite a competent institution to give an opinion on matters relevant to the case, which fall within the scope of the competence of the said authority. ${ }^{2}$ Both Regulation 1/2003 and Latvian Competition Law (hereinafter, Competition Law) provide for the possibility to participate and to issue opinions by respectively - the European Commission and the Latvian Competition Council. ${ }^{3}$ At the same time, Latvian general jurisdiction courts are rather reluctant to invite competition authorities. Courts are generally not obliged to follow any type of evidence submitted, even in the form of an expert's opinion, although these opinions tend to be followed in practice (Jerneva and Druviete, 2017).

While opinions of the European Commission, as well as those of the Latvian Competition Council, must not be treated as binding, there seems to be a need for a clearer status of such interventions. Once, addressing a request by the claimant to invite the European Commission to issue its opinion, a Latvian judge rather emotionally denied the request, noting that a Latvian court is independent in making its judgments and neither European nor Latvian

\footnotetext{
2 Art. 89 CPL.

3 Point 2 of Part 1 of Art. 7 of the Competition Law. This provision gives the Latvian Competition Council the right, but does not formally oblige it, to issue opinions on the compliance of the conduct of market participants with the rules of competition laws.
} 
authorities need to be invited to educate the judges. ${ }^{4}$ New amendments to the Competition Law ${ }^{5}$ (hereinafter, Draft Competition Law) provide that in case the court is not able to assess for itself whether access to certain evidence is crucial for the case of the claimant, it can request that the Competition Council issues an independent opinion and evaluates the relevance of specific evidence for the case. It seems, however, that the Draft Competition Law and amendments to the Latvian Civil Procedure Law (hereinafter, Draft CPL and collectively referred to as the Amendments) would be more effective if the courts were obliged to ask for such an opinion under specific circumstances (Jerneva and Druviete, 2017).

In interpreting the Estonian travaux préparatoires of the draft law, there are additional measures for an injured person to safeguard evidence such as, for example, the pre-trial taking of evidence. If there is suspicion that a potential opponent may start destroying evidence, the injured person may apply for pre-trial taking of evidence subject to paragraph 244 of the Code of Civil Procedure (hereinafter, COCP). In pre-trial taking of evidence the court, however, organises the collection of evidence only if (i) a request by the person seeking damages exists, as well as (ii) good reason to believe that evidence could be lost otherwise, or using the evidence afterwards could involve difficulties. In pre-trial taking of evidence, the court may also organise inspections, hear witnesses and request expert assessments (Pärn-Lee, 2017, p. 122).

There is no uniformity with regard to the procedure for the disclosure of evidence. This is bound to happen since each country's legal system is different and their legal history vary. Countries can also learn from best practices within the EU, as courts implement the Directive in light of their national laws. It is too early to predict the procedural outcomes at this stage.

\section{Procedure for the submission of evidence}

The procedure for the submission of evidence should deal with two aspects: the existence of pre-trial procedures, and prima facie proof of existence. Two CEE jurisdictions have clear regulations on pre-trial proceedings. Latvian Civil Procedure Law (hereinafter, CPL) provides for an opportunity to organise a preparatory session in order to decide on issues related to the organisation of the proceedings. Inter alia, the court will hear requests to provide evidence which is not at the disposal of the claimant.

${ }^{4}$ Case reference available upon request.

5 Draft law No. VSS-441, approved by the Meeting of State Secretaries on 08.09.2016. 
In Estonia, the authors of the draft law have provided additional measures for an injured person to safeguard evidence, for example, pre-trial taking of evidence. If suspicion exists that a potential opponent may start destroying evidence, the injured person may apply for pre-trial taking of evidence subject to paragraph 244 of the COCP. In pre-trial taking of evidence the court, however, organises the collection of evidence only if (i) a request by the person seeking damages has been made, and (ii) good reason exists to believe that evidence could be lost, or using the evidence afterwards could involve difficulties. In pre-trial taking of evidence, the court may also organise inspections, hear witnesses and request expert assessments (Pärn-Lee, 2017, p. 122).

With regard to the second issue of prima facie proof of existence, the sub issues dealt with should be the claim should not be frivolous in nature, are decisions of national authorities (competition council) amount to proof or lack thereof. Though there is no general mention about frivolous claims, court practice thus far is clear in not entertaining claims of frivolous nature.

With regard to accepting decisions of national authorities as prima facie proof of existence, there is no consensus. This varies not simply because of the law, but also due to court practice. There is reluctance in Latvia to consider decisions of the competition council. The situation is pretty much opposite in Estonia and Lithuania. This might be an issue stemming from lack of trust between institutions. This could also be an issue of different interpretations of the law. In either case, it is not in the interest of a smooth implementation of the Directive or achieving the purposes of the Directive.

\section{Criteria for the disclosure of evidence}

The Directive provides for proportionality concerning the request for the disclosure of evidence. There seems to be broad consensus on this. However, the implementation methods show slightly varying approaches.

The Draft CPL states that the request for evidence must be substantiated and proportionate. Proportionality is understood so that the request may only be submitted when the claimant has first submitted sufficient evidence to establish a prima facie proof of existence of the harm caused by the defendant. If the request for evidence is formulated in such a manner that it requests a category of evidentiary material, then such a category must be described in sufficient detail and precision in order for the other party and the court to be able to identify the type of evidence falling within the said category. Furthermore, it is also necessary to indicate the possible characteristics, 
subject and contents, as well as time-period when the said evidence was created. The Draft Competition Law is also giving additional guidance on the process of requesting evidence contained in the case files of the Latvian Competition Council or the European Commission. The Draft Competition Law fully follows the text of the Directive in this respect. However, to change the attitude of the courts and the authority, mere reference to the right of the court to give access to sensitive documents is insufficient. A more certain language and clear legal tests should be inserted into the law to highlight the importance of access to evidence which is not at the disposal of the claimant (Jerneva and Druviete, 2017).

The Draft Competition Law provides that in case the court is not able to assess for itself whether access to certain evidence is crucial for the case of the claimant, it can request for the Competition Council to issue an independent opinion and evaluate the relevance of specific evidence for the case. It seems, however, that the Amendments would be more effective if courts were obliged to ask for such an opinion under specific circumstances - the legislature should introduce a legal test, specifying the minimum line argumentation to be put forward by the claimant. If the claimant successfully meets such criteria, the judge should be obliged to invite the authority or the author of the respective documents to present its objective observations on the substance and relevance of the evidence. Given that the involvement of the Latvian Competition Council does not increase the costs of the procedure, this solution should be used at least until general jurisdiction courts feel more confident in making the relevant evaluation by themselves (Jerneva and Druviete, 2017).

In Lithuania, the new law introduces the principle of proportionality to be followed by the court while deciding on the granting of access to evidence. The law transposes the criteria established under Article 5(3) of the Damages Directive for the evaluation of the proportionality of the access request. In addition, Article 52(7) of the new Law on Competition of Lithuania obliges the court, before deciding whether to grant access to evidence, to allow the participants to the court proceedings to express their opinion within seven days about such a request. This novelty will make it possible to balance legitimate interests of all parties to the proceedings, and to avoid 'fishing expeditions' at the earliest stage (Mikelènas and Zaščiurinskaitè, 2017, p. 205).

With regard to proportionality, Estonian civil procedural law allows the court to refuse evidence or refuse taking the evidence if: ${ }^{6}$

- the evidence has been obtained by way of a criminal offence or unlawful violation of a fundamental right,

${ }^{6}$ Para. 238(3) COCP, Art. 5(3) a) and b). 
- the evidence is not accessible and, above all, if the witness's data or the location of a document is unknown, or if the relevance of the evidence is disproportionate to the time necessary for taking the evidence or other difficulties related thereto,

- the evidence is not provided, or the request for taking the evidence is not made in a timely manner,

- the need for providing or taking evidence is not substantiated,

- the participant in the proceeding requesting the taking of evidence fails to make an advance payment demanded by the court in order to cover the costs incurred upon the taking of evidence (Pärn-Lee, 2017, p. 118-119).

Requesting disclosure of evidence from the Estonian Competition Board, which is included in its files, and asking for its views on the proportionality of disclosure is currently not regulated in Estonian legislation. ${ }^{7}$ It is established in the draft law that the court requires the taking of evidence from the file of the Competition Board if that evidence is available in the file, and if it is impossible to take it from a party or third parties. The Competition Authority is entitled to express its views on the taking of the relevant evidence (Pärn-Lee, 2017, p. 121).

The bill for an amendment of the Protection of Competition Act (hereafter, BAPCA) (Bulgaria) does not go further than the Directive and reproduces the very same limitations, with respect to the disclosure of documents from the files of the competition authority. Requests for access to such documents are subject to a much stricter proportionality test, and leniency applications and settlement submissions enjoy absolute immunity ${ }^{8}$ (Petrov, 2017, p. 44). The Directive sets out minimum standards for the disclosure of evidence, allowing Member States to introduce rules 'which would lead to wider disclosure'. 9 Article 5 requires the disclosure of documents in national proceedings from the opposing party or any third party, subject to a reasoned request and court control. The national court must use a proportionality test to weigh the interests in favour of, and against disclosure. The court should consider, in particular, the materials supporting the access request, the scope and cost of disclosure, and whether the evidence that is to be disclosed contains confidential information ${ }^{10}$ (Petrov, 2017, p. 43-44).

In Croatia, the draft Act on antitrust damages provides that while deciding on disclosure requests, the court must apply the principle of proportionality, that is, it has to balance 'opposing interests in a given situation - the interests which would be favoured by the disclosure of the documents in question

\footnotetext{
7 Art. 6(10) and (11) of the Directive.

8 BAPCA proposal for a new Art. 118 PCA.

9 Art. 5(8) of the Directive.

10 Art. 5(3) of the Directive.
} 
versus those which would be jeopardised by such disclosure' (Galič, 2015, p. 105). Pursuant to Article 6(5) of the draft Act on antitrust damages, the court should balance the interest of all parties involved and, in particular, their interest: (a) to avoid disclosure where relevant facts contained therein may be established though other available evidence; (b) to specify evidence as precisely as possible considering the circumstance of the case and to order disclosure only of evidence relevant to the case; (c) to make sure that the scope and cost of discovery is not disproportionate to the value of facts trying to be established; and (d) to safeguard the protection of business secrets (Butorac Malnar, 2017, p. 76).

However, some ambiguity arises from the requirement of proportionality of disclosure entrenched in Article 6(4) of the Directive. The Draft act specifies more rigidly that a motion for disclosure must be specific, that is, contain the description of the nature, subject or content of the files of the requested documents; it must relate to the damages case; the party must prove that it failed to obtain these documents by itself prior to requesting disclosure, and must ensure the protection of efficient public enforcement of competition law. ${ }^{11}$ However, from a practical point of view, this will not be problematic; if anything, it provides a clearer guidance for the parties requesting disclosure while leaving untouched the right of the courts to observe that proportionality of disclosure is being observed (Butorac Malnar, 2017, p. 76).

In the Czech Republic, special rules apply with regard to competition authorities. Concerning information contained in the competition authority's file (but possibly also held by other parties, for instance, as a copy), the proportionality test should also take into account whether the request has been formulated specifically to cover such documents, whether the request is indeed connected to the action for damages and whether effectiveness of public procurement is not jeopardised. ${ }^{12}$ These requirements are more or less precisely contained in the Damages Act as well. ${ }^{13}$ In any event, the competition authority may be requested to disclose information contained in its file only if it cannot be reasonably accessed by other means ${ }^{14}$ (Petr, 2017, p. 102).

In Poland, Articles 18 to 21 of the draft Act on Claims for Damages for Infringements of Competition Law (hereinafter, ACD) have a procedural nature. Thus, these parts of the ACD set requirements addressed to procedural writs (motions for disclosure of evidence), grant the party the right to be heard before the court decides to disclose evidence, and set conditions under which

\footnotetext{
11 Art. 8(1) of the draft Act on antitrust damages.

12 Art. 6(4) of Damages Directive.

13 Sec. 16(1) and (2) of the Damages Act.

14 Sec. 15(5) and 16(4) of the Damages Act.
} 
the court dismisses a request for access to evidence, proportionality principle included $^{15}$ (Piszcz and Wolski, 2017, p. 226).

In Slovenia, the proportionality principle enshrined in the Directive is observed, as the claimant must produce the facts and evidence which enable a prima facie conclusion on the existence of the claim for damages when invoking his right of disclosure. As the Slovenian legal environment is not familiar with the standard of 'plausibility of the claim' used in the Directive, the drafters were forced to coin a new - similar type of standard, thus lessening the level of predictability and legal certainty. ${ }^{16}$ It is also worth noting that Article 62a of Prevention of Restriction of Competition Act (Sl. Zakon o preprečevanju omejevanja konkurence, hereinafter, ZPOmK-1) envisages a conditional right to demand disclosure of evidence for the defendant, who must produce facts and evidence which enable a prima facie conclusion that the damages claim is not substantiated. Such a solution frets away from the regime set forth by the Directive. It does, however, stress the importance of proportionality and control over potential strategic abuses of the disclosure regime for fishing expeditions. These concerns are further touched upon in the third and fourth paragraph of Article 62a, respectively, where the drafters have transposed the qualitative standards regarding the proportionality test from Article 6 of the Directive. Additional rules are laid down in Articles 62a and 62d of ZPOmK-1 for disclosure of evidence and information from the file of the competition authority. The treatment of confidential data and privileged communication is regulated in Article 62a of ZPOmK-1 (Vlahek and Podobnik, 2017, p. 286).

The acceptance of the proportionality principle provides for legal certainty. Although there is a certain amount of difference in accepting the scope of the term proportionality, the broad consensus amongst the various Member States aids in the implementation of the purpose of Chapter II of the Directive, that is, the disclosure of evidence.

\section{Restrictions on the disclosure of evidence}

The restrictions on the disclosure of evidence should be divided into four issues: commercially sensitive data, possibility to restrict access to certain parts of the file, professional privileges, and inadmissible evidence.

\footnotetext{
15 See draft Explanatory Notes accompanying the ACD, p. 18-20.

16 See Proposal of Act Amending and Supplementing the Prevention of Restriction of Competition Act (Sl. Zakon o spremembah in dopolnitvah Zakona o preprečevanju omejevanja konkurence) of 17.02.2017, p. 44.
} 
With regard to commercially sensitive data, approaches vary. However, the general rule is that anyone with contact to such information needs to either sign a non-disclosure agreement or pay an upfront deposit. Some countries also have penalties in place for disclosure of commercially sensitive data to third parties. Although the Directive aims to provide for the disclosure of evidence, it is responsive to the protection of commercially sensitive data. Most countries have transposed this part of the Directive into their national legislations.

With regard to the restriction of access, different countries have different approaches. In Lithuania, the new rules regarding the treatment of, and access to confidential information have been introduced under Article 52(5) of the new Law on Competition. The court is entitled to order disclosure of confidential information, although certain protective measures or their combination should be used, such as: identification of the parties to the proceedings who will be entitled to work with confidential case material ('confidentiality circle') and related duties, in order to ensure the protection of confidential information; prohibition to copy and disclose such information, etc. (Mikelènas and Zaščiurinskaitè, 2017, p. 205).

In Estonia, Article 5(3), only with regard to sub-clause (c) the draft law provides that the court may refuse evidence or to take evidence that contains a business secret or confidential information, especially concerning third parties and when, in the opinion of the court, it is not proportionate vis-a-vis with the evidence to prove it. (Pärn-Lee, 2017, p. 119). The measures currently available may be insufficient or even ineffective in protecting business secrets or confidential information in competition matters. To rectify this, the authors of the draft law proposed a system of confidentiality clubs/rings, which would have allowed the court to decide on access to such evidence, meaning that only the legal representatives of the parties would have had full access, complimented with a non-disclosure obligation; claimants, defendants and other parties to the procedure would not have had access to such evidence. The aim of this solution was for the infringers to not be able to hide behind the defence of business secret or confidentiality. However, the proposed measure was strongly opposed, thus the Ministry of Justice decided not to add it and to proceed with measures already available, even if they prove to be inefficient in damage claims concerning competition law infringements (Pärn-Lee, 2017, p. 120).

The Directive incorporates the recent jurisprudence of the CJEU, allowing claimants to specify 'categories' of documents, in order to facilitate the disclosure procedure. ${ }^{17}$ This would bring a substantial improvement to the

17 Case C-536/11 Bundeswettbewerbsbehörde v. Donau Chemie AG, ECLI:EU:C:2013:366 and Case C-365/12P Commission v. EnBW Energie Baden-Württemberg AG, ECLI:EU:C:2014:112. The latter case deals with access to documents according to Regulation 1049/2001. 
position of claimants in Bulgaria, since so far the courts refused to order the disclosure of documents unless they were properly identified and the request was supported by data that such documents exist and are in the other party's possession. ${ }^{18}$ The BAPCA rules do not go further than the Directive, and reproduce the very same limitations with respect to the disclosure of documents from the files of the competition authority. Requests for access to such documents are subject to a much stricter proportionality test, and leniency applications and settlement submissions enjoy absolute immunity ${ }^{19}$ (Petrov, 2017, p. 44).

The Directive requires national courts to have 'effective measures' at their disposal to protect confidential information which has been disclosed. The BAPCA transposition confirms this obligation to protect confidential information, but in reality such measures do not yet exist in Bulgaria. So far, all documents collected in the course of a civil action, including via mandated disclosure, become part of the case file, which can be accessed by third parties. Therefore, additional implementing regulations and guidance for the courts would be required on when and how to implement the redaction of sensitive documents, hearings behind closed doors, restrictions on the circle of persons allowed to see specific evidence ('confidentiality rings'), etc. (Petrov, 2017, p. 44-45).

With regard to professional privilege, the Estonian civil procedural law provides that legal representatives (including notaries) should not be heard as witnesses without the permission of the person in whose interests the duty to maintain confidentiality is imposed. This restriction concerns facts, which have become known to legal representatives during the performance of their professional duties (Pärn-Lee, 2017, p. 120). The drafters claim that the obligation set forth in Article 5(6) of the Directive is covered with the above named national civil procedural rule. However, there is doubt in this context as the legal privilege principle in EU law is much wider in scope than this interpretation only, for example applying also to documents emanating from the undertaking to an external lawyer, rather than only from an external lawyers to the undertaking (Pärn-Lee, 2017, p. 120; Roth and Rose, 2008). According to the general rules of the Croatian Civil Procedure $\operatorname{Act}^{20}$ (hereinafter, CPA), the opposing party may resist a court disclosure ordered for a number of justified reasons such as: attorney-client privilege, religious confession, professional secrecy, or if there is a risk of exposing him- or herself

18 Ruling No. 520 of 28.09 .2015 on case No. 2048/2015 of the SCC, Commercial Division, $2^{\text {nd }}$ Chamber.

19 BAPCA proposal for a new Art. 118 PCA.

20 Civil Procedure Act, Official Gazette - Narodne novine 53/91, 91/92, 58/93, 112/99, 88/01, 117/03, 88/05, 02/07, 84/08, 123/08, 57/11, 148/11, 25/13, 89/14. 
or a close family member to criminal prosecution or significant material damage. These are justifications pertinent to witness privileges that apply mutandi mutantis. The Draft Act on antitrust damages maintained these rules on opposing disclosure, explicitly giving full effect of the legal professional privilege, while specifying that the interest of a defendant to avoid actions for damages or avoid compensation is not a justifiable reason for withholding evidence (Butorac Malnar, 2017, p. 74).

In the Czech Republic, confidentiality of legal professional privilege (hereinafter, LPP) needs to be guaranteed. The protection of LPP is not provided for in the Czech legal order, even though in antitrust proceedings, the courts require the same standard of LPP protection as under EU law. According to the Damages Act, disclosure must not conflict with the professional secrecy of independent lawyers (advocates), which is nonetheless not identical to the notion of LPP. It is obvious that complex provisions on the LPP and its protection need to be adopted in Czech law (Petr, 2017, 101). In Slovenia, the treatment of confidential data and privileged communication is regulated in Article 62a of ZPOmK-1 (Vlahek and Podobnik, 2017, p. 286).

With regard to inadmissible evidence, anything access to which is restricted by the Directive (such as leniency and settlement submissions) is inadmissible. This is accepted universally as explained below. Typically, if the confidentiality of the disclosed information is breached, the court may decide that the evidence is inadmissible. This is not enshrined in Czech law, but incorporated into other draft acts or court practice.

\section{Disclosure of evidence by parties other than defendant}

There are two broad issues with regard to the disclosure of evidence by parties other than the defendant - types of documents (restrictions) and leniency/settlement. With regard to restrictions or permitting documents from third parties, there is no consensus. The procedures for accepting such documents are different as well.

The Latvian CPL prescribes that evidence, which is at the disposal of state institutions or third parties (including respondents), may be requested by the court. For the request to be made, a separate procedural document must be prepared by the claimant. In this document, the claimant must 'describe such evidence and provide their reasons for presuming that the evidence is in the possession of the person referred to'. ${ }^{21}$ In practice, this provision is interpreted

21 Part 2 of Art. 112 of Latvian Civil Procedure Law. 
so that a sufficiently precise name and description of contents needs to be provided. This procedure serves as an effective means to protect the interests of the defendant. For example, the defendant may respond to the court that no documents that conform to the description provided by the claimant exist. Where the documents proving the case are at the disposal of the authorities, the same rules apply and claimants are generally dependent on the subjective decision of the judge to request the evidence or deny the motion.

Lithuanian law does not recognise the discovery of evidence as it is understood and applied in the common law system. Following the Code of Civil Procedure, ${ }^{22}$ each party collects and submits to the court all available evidence that the party to the proceedings intends to refer to in the proceedings. In the event the party to the court proceedings cannot receive certain evidence related to the case on its own, it may request the court to order the disclosure of evidence related to the case and held by the other party to the proceedings or by a third party. As a general rule, the court will not order the disclosure of evidence at its own discretion (Mikelènas and Zaščiurinskaitè, 2017, p. 204).

In Hungary, Article 53(1) of the new Law on Competition establishes prioritisation of evidence in the same manner as under Recital 29 and Article 6(10) of the Damages Directive - disclosure from a competition authority of evidence included in its file is the last resort and is available only where no party or third party is reasonably able to provide that evidence. The new Law on Competition also directly establishes almost the same rules as the Damages Directive on access and the limitation of access to the file of the national competition authority, as well as of the European Commission (Miskolczi Bodnár, 2017).

Rules of disclosure already exist under Bulgarian law (Articles 161, 176(3), 190 and 191 of the Code on Civil Procedure, ${ }^{23}$ hereinafter, CCP), permitting a claimant to request the court to order the defendant or a third party to produce specific evidence (Petrov, 2017, p. 44).

In Croatia, disclosure may be obtained where the party requesting it makes it plausible that the opponent or a third party holds such evidence. If the party requesting disclosure is the claimant, he has to demonstrate the plausibility of his damages claim as well. The standard of showing plausibility has not been explicitly defined by the draft Act on antitrust damages. However, it is a common term in civil procedure, corresponding to the explanation given by the Directive, whereby the standard of plausibility is met by presenting 'reasonably available facts in a reasoned justification' (Butorac Malnar, 2017, p. 75-76).

22 28.02.2002, No. IX-743 (O.G. 2002, No. 36-1340) (with subsequent amendments).

23 Civil Procedure Code (Граждански проиесуален кодекс), promulgated in State Gazette No. 59 of 20.07.2007 (with subsequent amendments). 
In the Czech Republic, evidence in the file of the Office for the Protection of Competition (hereinafter, CCA) is somewhat accessible - any third party (that is, not a party to the CCA's proceedings) ${ }^{24}$ may be granted access to that file according to the Code of Administrative Procedure, ${ }^{25}$ if they are able to prove a sufficient legal interest thereupon, and provided that such an access to the file will not violate rights of the parties to the CCA's proceedings or the public interest. ${ }^{26}$ The CCA is, nonetheless, rather strict in this regard and generally does not allow third parties to inspect its files, even if these are alleged victims of an anti-competitive behaviour. The Supreme Administrative Court held in a series of recent judgments that in principle, alleged victims of (putative) anti-competitive conduct have sufficient legal interest to warrant their access to CCA's files ${ }^{27}$ - a change in the CCA's practice is, however, yet to materialise. Even if granted access to the file, third parties (even victims of an anti-competitive conduct) cannot be granted access to leniency and settlement applications and their accompanying documents ${ }^{28}$ (Petr, 2017, p. 97).

In Poland, to overcome the main obstacle in effective private enforcement (lack of access to evidence), Article 16(1) ACD grants the court the right to order the defendant or a third party to disclose evidence. The order can be issued at the plaintiff's request only when the plaintiff substantiated its claim, and provided that the plaintiff has committed that the requested evidence will be used only in the pending proceedings. A request for disclosure of evidence under the latter condition can be submitted to the court also by the defendant (Article 16(1) ACD in fine). If the evidence is included in a file of a competition authority then the court can order such evidence be disclosed only if obtaining it from the opposing party is not possible or such is excessively difficult (Article 16(2) ACD). The procedural parties, a third party as well as a competition authority can lodge a complaint concerning the court order on the disclosure of evidence (Article $23 \mathrm{ACD}$ ). Those parties can also demand for the court to change or repeal its order, if the circumstances that justified the order have changed (Article 24 ACD) (Piszcz and Wolski, 2017, p. 225-226).

The second issue in this context concerns leniency and settlement proceedings. According to some scholars, the Directive has an obvious bias

${ }^{24}$ It should be added in this regard that under the Czech Competition Act, victims of anticompetitive conduct are not participants to the proceedings before the CCA. See Section 21a of the Competition Act and the judgment of the Supreme Administrative Court of 02.10.2015, Ref. No. 4 As 150/2015.

25 Act No. 500/2004 Coll., Code of Administrative Procedure, as amended.

26 Code of Administrative Procedure, Sec. 38(2).

27 See e.g. the judgments of the Supreme Administrative of 11.08.2015, Ref. No. 6 As 43/2015, of 09.04.2014, Ref. No. 9 Afs 73/2013, or of 10.04.2014, Ref. No. 7 As 20/2014.

28 Competition Act, Sec. 21c(3) and (4). 
in favour of shielding leniency and settlement submissions from any disclosure, to the detriment of the right to full and effective compensation of the victims of competition law infringements (Mircea, 2017, p. 242-243). This stance runs counter to what the European Court of Justice decided so far, in its seminal decision in Pfleiderer. ${ }^{29}$ A similar view is expressed by the EU highest court in its decision in the case Donau Chemie. ${ }^{30}$ In Romania, a specific addition in this context concerns the penalties proposed by the Romanian government for a failure to properly apply the protection of leniency and settlements submissions, ranging from $0.1 \%$ to $1 \%$ of the turnover of the infringer (this is a huge sanction) if the latter is a legal person, and up to approximately EUR 1,200 for individuals (this is almost insignificant) (Mircea, 2017, p. 243).

Hungarian legislation provides limited exceptions to evidence disclosure, including leniency statements, settlement submissions or legally privileged documents (Miskolczi Bodnár, 2017, p. 147). The Bulgarian BAPCA rules do not go further than the Directive and, with respect to the disclosure of documents from a file of a competition authority reproduce exactly the same limitations. Requests for access to such documents are subject to a much stricter proportionality test, and leniency applications and settlement submissions enjoy absolute immunity ${ }^{31}$ (Petrov, 2017, p. 44).

Separate attention, following the provisions of the Directive, is given to evidence held in the case files of the authorities, but which refers to the market participant, who successfully applied for leniency. The Latvian Competition Council has, so far (even prior to the Amendments), defended the commercial interests of the participants of the leniency programme, as well as those of other parties to the cases. Specific rules have also applied with respect to access to leniency material. Access has been allowed only after the investigation was closed. However, the legislation was silent about access to the file for injured persons other than participants to the proceedings. Therefore, usual rules under the Code of Civil Procedure applied. In general, the material of the Competition Council, other than the restricted one, could be subject to a court access order upon a reasonable request of a party to the proceedings. Non-confidential versions of infringement decisions of the competition authority have been published officially and so they have been publicly available (Jerneva and Druviete, 2017).

29 Case C-360/09 Pfleiderer v. Bundeskartelamt, ECLI:EU:C:2011:389, decision of the Grand Chamber of 14.06.2011.

30 Case C-536/11 Bundeswettbewerbsbehörde v. Donau Chemie AG, ECLI:EU:C:2013:366, decision of 06.06.2013.

31 BAPCA proposal for a new Art. 118 PCA. 
In Lithuania, in contrast to previous regulation, the new Law on Competition limits disclosure protection only to leniency statements of the cartelists ${ }^{32}$ as well as settlement submissions. Leniency statements of the cartelists will not be accessible to anyone, not even to other cartelists. Analogous rules will apply with respect to settlement submissions, the latter having only been introduced in Lithuania with the adoption of the new Law on Competition. Thus, preexisting documents submitted as annexes to a leniency statement are no longer exempt from disclosure.

These rules narrow the scope of previous legal protection, which used to apply in Lithuania with respect to all leniency material submitted by the leniency applicant qualifying for the immunity (for example, pre-existing documents attached to the leniency statement). Thus, until the implementation of the Damages Directive, the Competition Council was not entitled to disclose any of the leniency materials submitted by the immunity recipients to claimants for damages compensation (Mikelènas and Zaščiurinskaité, 2017, p. 206-207).

The aforementioned novelty, together with other specific rules applied to immunity recipients introduced by the new Law on Competition balances, nevertheless, the goals of public and private enforcement. On the one hand, as indicated in Recital 26 of the Damages Directive, leniency programmes are important tools for the detection and efficient prosecution of, and the imposition of penalties for, the most serious infringements of competition law. At the same time, damages claims in cartel cases generally follow infringement decisions based on a leniency application. Hence, leniency programmes are also important for the effectiveness of actions for damages in cartel cases. On the other hand, by limiting access only to leniency statements, and not to all leniency materials, the law broadens the possibilities for the victims of cartels to claim damages compensation.

In Croatia, given that the Directive regulates disclosure exemptions via a maximum harmonisation rule, those have been implemented fully and precisely. Accordingly, documents that may never be disclosed include settlement submissions and leniency statements. Here it is important to note that Croatian competition law does not envisage a settlement procedure in public enforcement. Therefore, this provision is meant to safeguard settlement procedures before the Commission or any other NCA according to their national competition law ${ }^{33}$ (Butorac Malnar, 2017, p. 78).

In Slovakia, these provision which at least partially deal with the protection of evidence used by the Antimonopoly Office of the Slovak Republic

32 Following the Law on Competition, leniency applications may also be submitted by a party to a resale price maintenance agreement. However, access restriction to its leniency statement should not apply as they do in case of leniency statements submitted by cartelist.

33 Art. 3(26) of the draft Act on antitrust damages. 
(hereinafter, AMO), the integrity of its investigations as well as effectiveness of measures meant to enforce competition law via public (administrative) law remained separated from Act No. 136/2001 Coll. on Protection of Economic Competition and Amending Act of the Slovak National Council No. 347/1990 Coll. On Organization of Ministries and Other Central Bodies of State Administration of the Slovak Republic as Amended (hereinafter, APEC), even though the APEC contains detailed provisions on the protection of leniency applications, disclosure of evidence etc. ${ }^{34}$ Hence, there is a strict distinction between the protection of leniency applications and files of the AMO for public law purposes (APEC) and for civil claims (Act 350/2016) (Blažo, p. 257-258).

The Czech Damages Act ${ }^{35}$ neatly absorbs the non-disclosure of leniency statements (excluding pre-existing information) and settlement submissions, ${ }^{36}$ including the procedure whereby the court may ascertain, if need be with the help of the CCA, whether the requested information is indeed a leniency statement or settlement submission. ${ }^{37}$ In addition, information prepared specifically for the purposes of the proceedings conducted by the competition authority, information prepared by the competition authority and sent to the parties, as well as settlement submissions that have been withdrawn, may all be disclosed only after the proceedings of the competition authority's have been closed. ${ }^{38}$ The Damages Act transposes these provisions, however, with several modifications unaccounted for in the explanatory memorandum. Firstly, whereas the Directive protects information prepared specifically for the purpose of the proceedings (excluding pre-existing information), the Czech Act protects information submitted in the proceedings. Secondly, the Directive protects information prepared and sent by a competition authority, whereas according to the Act, sending is not required. Finally, such information is protected by the Damages Act only as long as the competition authority's decision closing the investigation has not entered into force yet. Presumably therefore, should the case have been concluded before a formal investigation was actually initiated, and thus without a decision, such information may never be disclosed. ${ }^{39}$ The protection afforded by the Czech Damages Act is,

34 APEC, § 40, § 41.

35 Damages Act, Sec. 15(1) and Sec. 2(2) (a) and (b).

36 Art. 6(6) and Art. 2(16), (17) and (18).

37 Damages Act, Sec. 15(2) and (3).

38 Damages Directive, Art. 6(5).

39 The same provision is nonetheless contained in Sec. 15(4) of the Damages Act whereby such information may be disclosed also when preliminary investigation is concluded without opening a formal investigation. 
therefore, significantly wider than that of the Damages Directive (Petr, 2017, p. 101-102).

Following the Damages Directive, the Polish ACD in Article 17 includes provisions protecting efficient public enforcement of competition law. Accordingly, it is not allowed to disclose leniency statements and settlement submissions, a part from that part of the document that does not constitute the leniency statement or settlement submission - this part of the document can be disclosed. Furthermore, information created specifically for the purposes of the proceedings of the competition authority, as well as settlement submissions that have been withdrawn, can be disclosed only after the proceedings have been completed (Article 17(2) ACD) (Piszcz and Wolski, 2017, p. 226).

The purpose behind the non-disclosure of leniency and settlement documents is separate for the public and private competition law domain. The issue that arises out of this is "not the separation itself, but how courts interpret it'. Countries with an advanced capacity to deal with competition matters make this distinction clear. However, countries where competition law functions only to a limited extent, either disclose too much or fail to disclose anything, hurting one of the parties. The Directive and cross assimilation of best court practices should, in the future, aid in making a clear distinction between public and private competition law proceedings, thus safeguarding the interest of the respective parties.

\section{Consequences of a failure to comply with a request to submit evidence}

This part of the articles should focus on two large issues: pecuniary penalties available to courts, and the ability of the courts to presume the establishment of facts due to non-compliance by parties to submit evidence.

Article 8 of Directive 2014/104/EU states that:

1. Member States shall ensure that national courts are able effectively to impose penalties on parties, third parties and their legal representatives in the event of any of the following: (a) their failure or refusal to comply with the disclosure order of any national court; (b) their destruction of relevant evidence; (c) their failure or refusal to comply with the obligations imposed by a national court order protecting confidential information; (d) their breach of the limits on the use of evidence provided for in this Chapter.

2. Member States shall ensure that the penalties that can be imposed by national courts are effective, proportionate and dissuasive. The penalties 
available to national courts shall include, with regard to the behaviour of a party to proceedings for an action for damages, the possibility to draw adverse inferences, such as presuming the relevant issue to be proven or dismissing claims and defences in whole or in part, and the possibility to order the payment of costs.

There are two keys aspects to this issue. First, there should be "noncompliance 'and, second, the measures or penalties available are effective, proportionate and dissuasive. However, this is not implemented universally across the eleven CEE jurisdictions. The pecuniary aspect of a penalty can be divided into countries with ineffective measures, countries with mixed measures, and countries with effective measures. Drawing adverse inferences, such as presuming the relevant issue to be proven or dismissing claims and defences in whole or in part, should be explained separately. Estonia and Slovakia have pecuniary measures that are currently ineffective.

In Latvia, for example, when a party fails to comply with the order of the court to submit specific documents, the court may impose a fine of up to EUR 14,000 for natural persons and EUR 140,000 for legal entities. Other Member States decided in favour of fines, expressed as a percentage of the turnover of the undertaking concerned. In Slovakia, the possible pecuniary sanction for refusing to provide a document is also quite low (up to EUR 500 and EUR 2,000 for repeat offenders); in Estonia it is up to EUR 3,200. These amounts are insufficient to motivate the offender to assist the claimant in proving his case. For example, in Latvian competition damages litigation practice there has been at least one case where the defendant ignored the order to submit evidence for the duration of at least two years (PKL Flote case). It is clear that low fines are neither effective nor proportionate nor dissuasive, as required by the Damages Directive, in cases of high damages claims. These measures may, therefore, not be preventive enough, considering the economic dimension of the potential damages claim from a competition law infringement; in fact, it may even be more worthwhile to pay the fine than providing the requested evidence.

Romania is a country with mixed measures. One specific addition in this context can be found in the penalties proposed by the Romanian government for failure to properly apply the protection of leniency and settlements submissions, ranging from $0.1 \%$ to $1 \%$ of the turnover of the infringer (this is a huge sanction), if the latter is a legal person, and up to approximately EUR 1,200 for individuals (this is almost insignificant) (Mircea, 2017, p. 243).

The Lithuanian approach with regard to pecuniary penalty has evolved. The previous law and Code of Civil Procedure were both silent on how the court should treat situations when the defendant or other party does not comply with the court's order to provide evidence, even though, in practice, the courts 
applied the contra spoliatorem principle in exceptional cases. In addition, the new Law has introduced a significant (up to EUR 10,000) penalty for the destruction of evidence as well as for failure to comply with the confidentiality order (Mikelènas and Zaščiurinskaitè, 2017, p. 207). An evolution of fines is also noticeable in Bulgaria. Prior to the Directive, Bulgarian law (Article 161, 176(3), 190 and 191 CCP) allowed for a claimant to request the court to order the defendant, or a third party, to produce specific evidence. Refusal to comply is sanctioned with fines for contempt of court in the amount of up to BGN 1,200 (approx. EUR 600). This amount is clearly insignificant where the value of the claim is substantial, such as in antitrust damages cases. Thus, the new limits for fines introduced with the BAPCA specifically for obstruction of justice in relation to claims under the PCA (up to BGN 500,000 - approx. EUR 250,000) will have an important disciplinary effect (Petrov, 2017, p. 44).

Hungarian legislation introducing fines tries to ensure that courts are able to disclose relevant evidence - hence, Section 88/Q(1) of MCA follows Article 8(1) of the Directive. The list of prohibited acts and omissions is the same as in the Directive, but the maximum amount of the fine is set at only HUF $50,000,000^{40}$ (EUR 160,000). Court practice should answer whether this will prove to be an 'effective method' in the meaning of Article 8(1) of the Directive (Miskolczi Bodnár, 2017, p. 147). In Croatia, the Draft Act on antitrust damages sanctions non-compliance with a court disclosure order in the following manner: (a) facts that should have been determined by the evidence will be considered established, ${ }^{41}$ and (b) the party opposing discovery (or who had destroyed or tried to destroy evidence) may be heavily fined the fine for undertakings ranges between HRK 10,000 up to maximum of $1 \%$ of their total turnover in the last year for which financial statements have been completed; fines for responsible persons or individuals range between HRK 500 to HRK 50,00042 (Butorac Malnar, 2017, p. 74).

In Slovenia, Article 8 of the Directive will be transposed via Articles 62e and $62 \mathrm{f}$ of ZPOmK-1. Article 62e governs situations where a party (expressly or tacitly) does not abide by a court's final decision on evidence disclosure by hiding or destroying the relevant evidence. In such cases, sanctions pursuant to the law on civil procedure regarding non-compliance with a court decision to submit documents are to be applied. If the person refusing to fulfil a court's final decision on evidence disclosure is not a party to the dispute, the court will execute such a decision ex officio pursuant to the rules on enforcement proceedings. Article $62 \mathrm{f}$ of ZPOmK-1 vests the court with the prerogative to issue fines of up to EUR 5,000 for natural persons or up to EUR 50,000 for

\footnotetext{
40 Sec. $88 / \mathrm{Q}(1)$ and (2) of MCA.

41 Art. 6(8) of the draft Act on antitrust damages.

42 Art. 10(2) of the draft Act on antitrust damages.
} 
legal persons, sole entrepreneurs, attorneys and candidate attorneys, when such persons refuse to fulfil or act contrary to a court's measure regarding the protection of confidential information (Vlahek and Podobnik, 2017, p. 287).

The Czech Republic probably has the most comprehensive system in terms of penalties. When the obligation to disclose evidence is not fulfilled, the court may impose a fine of up to CZK 10,000,000 (EUR 400,000) or $1 \%$ of the undertaking's annual turnover. ${ }^{43}$ The same fine may be imposed on those who make the fulfilment of such a duty impossible or more complicated; ${ }^{44}$ this presumably applies to cases of destruction of relevant evidence. ${ }^{45}$ For breaching the duty to protect the confidentiality of the disclosed information, a fine of up to CZK 1,000,000 (EUR 40,000) may be imposed. ${ }^{46}$ Such fines may be imposed repeatedly, ${ }^{47}$ within the period of five years since the obligation was breached. ${ }^{48}$ All companies making up an economic entity are jointly and severely liable for the fine, ${ }^{49}$ which is the first case of collective liability for fines in the Czech legal order. Finally, the court may decide that the one who has failed to disclose the evidence or has breached its confidentiality should bear the costs of the proceedings ${ }^{50}$ (Petr, 2017, p. 103).

With regard to the 'aspect of drawing adverse inferences, such as presuming the relevant issue to be proven or dismissing claims and defences in whole or in part', it seems most countries are in concurrence with the Directive. In Latvian, the claimant may refer to the rules of the CPL, which allow the claimant in this case to presume that the facts, which needed to be proven by the non-submitted evidence, are true and accurate. This solution is not without defect as it can only be used where there is other, indirect evidence of the relevant facts. In Lithuania, both the previous Competition law and the Code of Civil Procedure have been silent on how the court should treat a situation when the defendant or other party does not comply with the court's order to provide evidence, even though, in practice, the courts applied the contra spoliatorem principle in exceptional cases. However, the new Competition law directly establishes the contra spoliatorem principle, that is, presumption that the relevant issues are proven or dismissing claims and defence, for failure or refusal to comply with a disclosure order as well as for the destruction of evidence (Mikelènas and Zaščiurinskaitè, 2017, p. 207). According to Estonian

\footnotetext{
43 Damages Act, Sec. 20(1) and (2).

${ }^{44}$ Damages Act, Sec. 20(1)(b).

45 Damages Directive, Art. 8(1)(a).

46 Damages Act, Sec. 21(1).

47 Damages Act, Sec. 23(2).

48 Damages Act, Sec. 22(1).

49 Damages Act, Sec. 22(3).

50 Damages Act, Sec. 32.
} 
civil procedural rules, if a party must fulfil an obligation to submit a document to the court, or the court is convinced after hearing the opposing party that the party has not looked for the document carefully, the court may approve the transcript of the document submitted to the court by the person providing the evidence, and if no transcript of the document has been presented, the court may deem the statements concerning the nature and content of the non-submitted document made by the person who requested the evidence to be proven $^{51}$ (Pärn-Lee, 2017, p. 121).

Romanian draft law for the implementation of the Directive is, with respect of the disclosure of evidence, basically a translation of the corresponding parts of the Directive. The relevant provisions have the same numbering as those of the Directive, that is, from Article 5 to Article 8. Hungarian legislation introduced an important change whereby if the obligated party fails to provide the requested evidence, the court is entitled to accept the fact - for the support of which the evidence was requested - as true..$^{52}$ The preventive effect of this rule is much more serious than a potential fine; only limited exceptions apply to evidence disclosure, including the leniency statement, the settlement submission or legally privileged documents (Miskolczi Bodnár, 2017, p. 147). In Bulgaria, where a party resists a disclosure order, the judge is empowered to draw prejudicial consequences against it. ${ }^{53}$ However, this sanction is important only where the evidence confirms or refutes the existence of a specific-fact that is crucial for the position of one of the parties (Petrov, 2017, p. 44).

The Slovakian Civil Disputes Code copied also all non-pecuniary alternatives of the sanctions: presuming the relevant issue to be proven, dismissing claims and defences in whole or in part. These non-pecuniary sanctions can be employed only if pecuniary sanction appears to be ineffective (Blažo, 2017, p. 258). In the Czech Republic, in addition to pecuniary penalties, if the obligation to disclose information is breached or made impossible, there is a legal fiction that what was to be proven by that evidence is in fact deemed to have been proven. ${ }^{54}$ Conversely, if the confidentiality of the disclosed information is breached, the court may decide that the evidence is inadmissible 55 (Petr, 2017, 103).

Thus with regard to penalties, pretty much all countries are in agreement as far as the concept of omnia praesumuntur contra spoliatore. However, there are gaps when it comes to the effectiveness of the respective measures in terms of pecuniary penalties. This does not bode well for the future - the effective

\footnotetext{
51 Para. 283(2) COCP.

52 Art. 88/Q(5) MCA.

53 Art. 161CCP.

54 Damages Act, Sec. 28(1).

55 Damages Act, Sec. 28(2).
} 
application of the Directive will be ensured only if those erring countries make the necessary amendments to their national legislations.

\section{Conclusion}

The transposition of the Directive into the national laws of CEE countries is varied. Some countries have absorbed the bulk of the rules of the Directive. This has led to improvements with regard to disclosure of evidence. However, there are jurisdictions that must iron out defunct and disruptive practices. The Directive envisages a balance between public and private actions with regard to competition law. This does not mean that the implementation of the goals of the Directive is automatic. Countries without great exposure to competition matters need to address those inequities between public and private matters, as well as between balancing the interests of disgruntled claimants and protecting the commercially sensitive data of the defendants. There is a need for cohesion for the successful implementation of the Directive with respect to the disclosure of evidence in competition matters.

\section{Literature}

Blažo, O. (2017). Slovakia. In: A. Piszcz (ed.), Implementation of the EU Damages Directive in Central and Eastern European Countries (247-262). Warsaw: University of Warsaw, Faculty of Management Press.

Butorac Malnar, V. (2017). Croatia. In: A. Piszcz (ed.), Implementation of the EU Damages Directive in Central and Eastern European Countries (55-84). Warsaw: University of Warsaw, Faculty of Management Press.

Galič, A. (2015). Disclosure of Documents in Private Antitrust Enforcement Litigation. Yearbook of Antitrust and Regulatory Studies, 8(12), 99-126.

Jerneva, J. and Druviete, I. (2017). Latvia. In: A. Piszcz (ed.), Implementation of the EU Damages Directive in Central and Eastern European Countries (157-178). Warsaw: University of Warsaw, Faculty of Management Press.

Mikelènas, V. and Zaščiurinskaitė, R. (2017). Lithuania. In: A. Piszcz (ed.), Implementation of the EU Damages Directive in Central and Eastern European Countries (179-210). Warsaw: University of Warsaw, Faculty of Management Press.

Mircea, V. (2017). Romania. In: A. Piszcz (ed.), Implementation of the EU Damages Directive in Central and Eastern European Countries (237-246). Warsaw: University of Warsaw, Faculty of Management Press.

Miskolczi Bodnár, P. (2017). Hungary. In: A. Piszcz (ed.), Implementation of the EU Damages Directive in Central and Eastern European Countries (127-156). Warsaw: University of Warsaw, Faculty of Management Press. 
Pärn-Lee, E. (2017). Estonia. In: A. Piszcz (ed.), Implementation of the EU Damages Directive in Central and Eastern European Countries (109-126). Warsaw: University of Warsaw, Faculty of Management Press.

Petr, M. (2017). Czech Republic. In: A. Piszcz (ed.), Implementation of the EU Damages Directive in Central and Eastern European Countries (85-108). Warsaw: University of Warsaw, Faculty of Management Press.

Petrov, A. (2017). Bulgaria. In: A. Piszcz (ed.), Implementation of the EU Damages Directive in Central and Eastern European Countries (25-53). Warsaw: University of Warsaw, Faculty of Management Press.

Piszcz, A. (ed.). (2017). Implementation of the EU Damages Directive in Central and Eastern European Countries. Warszawa: University of Warsaw, Faculty of Management Press.

Piszcz, A. and Wolski, D. (2017). Poland. In: A. Piszcz (ed.), Implementation of the EU Damages Directive in Central and Eastern European Countries (211-236). Warsaw: University of Warsaw, Faculty of Management Press.

Roth, P.M. and Rose, V. (2008). Bellamy \& Child. European Community Law of Competition. Oxford: Oxford University Press.

Vlahek, A. and Podobnik, K. (2017). Slovenia. In: A. Piszcz (ed.), Implementation of the EU Damages Directive in Central and Eastern European Countries (263-296). Warsaw: University of Warsaw, Faculty of Management Press. 